\title{
INTERPRETATION AND IMPLEMENTATION OF EUROPEAN STANDARDS OF HUMAN RIGHTS AND FUNDAMENTAL FREEDOMS PROTECTION IN UKRAINIAN COURT PRACTICE: PROBLEMS AND PROSPECTS
}

\section{INTERPRETÁCIA A IMPLEMENTÁCIA EURÓPSKYCH NORIEM PRE OCHRANU LUDSKÝCH PRÁV A ZÁKLADNÝCH SLOBÔD V UKRAJINSKEJ SÚDNEJ PRAXI: PROBLÉMY A PERSPEKTÍVY}

\author{
Svitlana Karvatska \\ Institute of International Relations Taras Shevchenko National University of Kyiv, \\ Yuriy Fedkovych Chernivtsi National University, Law Faculty
}

https://doi.org/10.33542/SIC2019-1-04

\begin{abstract}
The Research shows that an essential but complicated question rises when it comes to the implementation of European Court of Human Rights (ECHR) practice in Ukrainian courts. Problems that hinder national courts' effective operation while implementing legal principles of the European court indicate that the Supreme Court of Ukraine must elaborate conceptual approaches and methods to ensure European standards in Ukrainian courts. Also to develop recommendations on an adequate and equal application of the Convention norms and European Court of Human Rights practice when administering justice.
\end{abstract}

\begin{abstract}
Štúdiou sme poukázali na hlavné problémy interpretácie a implementácie európskych štandardov l’udských práv a základných slobôd v ukrajinskej právnej praxi. Výskum preukázal, že prirodzenou, ale dôležitou otázkou, ked’ hovoríme o implementácii praxe Európskeho súdu pre l'udské práva (ECHR), zo strany ukrajinskych súdov sú príslušné postupy a právne dôvody. Zistilo sa, že problémy, ktoré vznikajú pri činnosti vnútroštátnych súdov pri využivaní právnych stanovísk Európskeho súdu naznačujú, že je úlohou najvyššieho súdu Ukrajiny formulovat' koncepčné prístupy a metódy použivania európskych noriem súdmi, vypracovat' odporúčania týkajúce sa ich správneho a spravodlivého uplatňovania v právnej praxi.
\end{abstract}

\section{INTRODUCTION.}

The adoption of the Convention of Human Rights and fundamental freedoms protection on November $4^{\text {th }}, 1950^{1}$ became a revolutionary event in international law - the Convention

Council of Europe, European Court of Human Rights. European Convention on Human Rights: from 4 Nov. 1950 (as amended by Protocols Nos. 11 and 14, supplemented by Protocols Nos. 1, 4, 6, 7, 12 and 13). URL: http://www.echr.coe.int/Documents/Convention_ENG.pdf. 
not only established a list of citizens' rights and freedoms, as it was done in General Declaration of Human Rights, but also created special institutions authorized to carry out the observation of its regulations, legal and quasilegal control and to consider actions of the individuals $v$. the states ${ }^{2}$. The judge of the European Court of Human Rights, G. Fitzmaurice wrote, "European Convention of human rights protection was the Convention of a new type, never known before; it stipulated for the state members the obligations never taken by the governments before" 3 . Nowadays, interpretations and implementations analysis and investigations of the European Conventional standards of human rights and fundamental freedoms protection in the Ukrainian national legal practice is of supreme interest, especially, in the context of existing problems and possible ways of their solution.

\section{NORMATIVE AND LEGAL RELEVANCE FOR THE ACTUAL IMPLEMENTA- TION OF ECHR PRACTICE IN THE NATIONAL LEGISLATION OF UKRAINE}

Having acceded to the Convention of Human Rights and fundamental freedoms protection in 1950, the state of Ukraine recognized the European Court of human rights jurisdiction in questions of the Convention and its Protocols interpretation by coordinating national legislation in accordance with European standards. The mechanism of the Conventional rights protection puts on the European Court of Human Rights a dual function. The first is to organize an individual control in case of the decisions about this or that law violation by a state member of the Convention. The second is to work out the principles and standards of human rights protection. This is stipulated by the Convention norms which are of sufficiently abstract character, and they need to be constantly interpreted by the Court. Here it's worth citing J. McBride, who states: "However, from different existing approaches, which may be used to interpret legal texts, the only one, meeting the European Court of human rights norms will guarantee the application of these standards according to international obligations to ensure the determined in the Convention rights and freedoms"4. The Convention of Court influenced not only international standards of human rights protection, but also the formation of those standards on national level.

On July $17^{\text {th }}$, 1997 the Supreme Council (Verkhovna Rada) of Ukraine ratified the Convention of Human Rights and Fundamental Freedoms protection of 1950, which became valid for Ukraine on September $11^{\text {th }}$, 1997. This problem is in the focus of modern state policy, owing to legal and law-enforcement systems reforms, legal education system. This is a priority support guideline on the part of the leading international organizations and their cells in Ukraine - the Council of Europe Office, projects Coordinator of OSCE in Ukraine and oth$\mathrm{ers}^{5}$. On a state level this problem is directly watched over by the Governmental commissioner in cases of the European Court of Human Rights ${ }^{6}$. According to the decree of the Cabinet of Ministers of Ukraine "About measures, concerning the implementation of Ukraine's Law" the law "About implementation of the decisions and application of the European Court on human rights practice" was brought into force on May $31^{\text {st }}, 2006$ № 784. In accordance to

2 MAZUR M. V., TAGIEV S. R., BENITSKIY A. S., KOSTITSKIY V. V. Tlumachennya ta zastosuvannya Konventsiï pro zahist prav lyudini y osnovopolojnih svobod Cvropeyskim sudom z prav lyudini ta sudami Ukraïni: navch. posib. Lugansk: RVV LDUVS, 2006. S. 19.

3 MAKBRAYD Dj. Printsipi, scho viznachayut tlumachennya ta zastosuvannya Cvropeyskoï konventsiï z prav lyudini. V: Jukovska O. L. (red..). Evropeyska konventsiya z prav lyudini: osnovni polojennya, praktika zastosuvannya, ukraïnskiy kontekst. Kiïv: ZAT "VIPOL", 2004. S. 761.

4 European Court of Human Rights. National Union of Belgian Police v. Belgium judgment of 27 October 1975, Separate Opinion of Judge sir Gerald Fitzmaurice. URL: http://www.echr.coe.int.

5 KRETOVA I. YU. Tlumachennya prava: doktrini, rozvinuti Cvropeyskim Sudom z prav lyudini: dis. kand. ... yurid. nauk: 12.00.01. Harkiv, 2015. S. 155.

6 Uryadoviy upovnovajeniy u spravah Evropeyskogo sudu z prav lyudini. Ministerstvo yustitsiï Ukraïni. Ofitsiyniy vebsayt. URL: http://old.minjust.gov.ua/8030.. 
that, the Ministry of Justice appoints the Governmental commissioner for cases of the European Court of Human Rights. He represents Ukraine in the European Court on Human Rights when the questions of the Convention of Human Rights and fundamental freedoms protection are discussed. He also reports about the fulfillment of the European Court on human rights decisions $v$. Ukraine ${ }^{7}$.

According to article 1 of Ukraine's Law "About the Convention of human rights and fundamental freedoms protection of 1950 ratification, First protocol and protocols № 2, 4, 7 and 11 to the Convention" Ukraine completely recognizes on its territory the validity of article 25 of the Convention of human rights and fundamental freedoms protection of 1950. Ukraine entrusts the European commission on human rights to take appeals from any person, nongovernment organization or a group of persons, addressed to the Council of Europe Secretary General about violation by Ukraine the Convention rights. Ukraine recognizes Article 46 of the 1950 Convention of human rights and fundamental freedoms protection as obligatory, also Ukraine acknowledges the European Court of Human Rights jurisdiction in all the questions, concerning the Convention interpretation and application ${ }^{8}$. To solve the question of implementation of standards of the European Court on human rights in national law, a separate law has been adopted in Ukraine - the Law of Ukraine "About carrying out the decisions and the use of the European Court of Human Rights practice" of February $26^{\text {th }}, 2006$. Article 2 of this Law accentuates, that the Court's decisions are obligatory to be carried out according to article 46 of the Convention. In accordance with article 17 of Ukraine's Law "About fulfillment of the decisions and application of the European Court of Human Rights practice", the courts in their activity use the Convention and the Court's practice as the source of law ${ }^{9}$. The given principle is developed also in other deeds of national legislation. So, the Code of administrative legal procedure of Ukraine of June $6^{\text {th }}, 2005$ states directly, that "the Court exercises the principle of legal supremacy taking into consideration the European Court on human rights practice" 10 . Criminal procedural code of Ukraine of April 13 $3^{\text {th }}, 2012$ runs, that "the principle of legal supremacy in criminal procedure is used in correspondence with the European Court on human rights practice" 11 . These regulations make the normative-legal grounds for practical implementation of theoretical conclusions of the Court's practice use, while interpreting human rights regulations.

The Law of Ukraine "About judicial system and judges' status" of July $7^{\text {th }}, 2010$ was amended on April 1 $1^{\text {st }}, 2015$ on the basis of the Law of Ukraine "About the guarantee of rights to fair justice" of February $12^{\text {th }}, 2015$. It determined "judicial authority organization and administration of justice in Ukraine, functioning on the basis of legal supremacy in accordance with the European standards and secure fair justice for everybody". Item 1, article 92 of this Law stressed judges' disciplinary liability "deliberate or connected with evident inadvertence by the judge, who took part in the decree resolution, violation of human rights and fundamental freedoms". Unfortunately, still valid in Ukraine Law "About judicial system and judges'

7 Pro zahodi schodo realizatsiï Zakonu Ukraïni «Pro vikonannya rishen ta zastosuvannya praktiki Evropeyskogo sudu z prav lyudini»: Postanova Kabinetu Ministriv Ukraïni vid 31 travnya 2006 r. № 784. Ofitsiyniy visnik Ukraïni. 2006. № 22. Ct. 1655 zi zminami.

8 Div.: Pro ratifikatsiyu Konventsiï pro zahist prav lyudini i osnovopolojnih svobod 1950 r., Pershogo protokolu ta protokoliv № 2, 4, 7 ta 11 do Konventsiï: Zakon Ukraïni vid 17 lipnya 1997 r. № 475/97-VR. Vidomosti Verhovnoï Radi Ukraïni. 1997. № 40. Ct. 263.

9 Pro vikonannya rishen ta zastosuvannya praktiki Evropeyskogo sudu z prav lyudini: Zakon Ukraïni vid 23 lyutogo 2006 r. Vidomosti Verhovnoï Radi Ukrä̈ni. 2006. № 30. Ct. 260 zi zminami.

10 Kodeks administrativnogo sudochinstva Ukraïni. CHastina 2 statti 8. Vidomosti Verhovnoï Radi Ukraïni. 2005. № 3536, № 37. St. 446. zi zminami.

11 Kriminalniy protsesualniy kodeks Ukraïni. CHastina 2 statti 8. Vidomosti Verhovnö̈ Radi Ukrä̈ni. 2013. № 9-10, № 1112, № 13. St. 88. zi zminami. 
status" doesn't contain the above mentioned data, hinders courts activity and restricts judges' verdicts in the sphere of human rights and the European Court of Human Rights practice ${ }^{12}$.

At the same time, one more aspect of this question is important. "Discrepancy between legal proceedings of national courts and the ECHR (European Court of Human Rights) can lead to the loss of trust to national courts, on the one hand, and excessive overloading with the quantity of people's appeals to the ECHR and complication of its work, on the other hand"13. In addition, the Constitutional Court of Ukraine as its main objective should ensure the supremacy of the Constitution of Ukraine, and not coordinate legal practice. However, in majority of cases the supremacy of the Constitution of Ukraine is not ensured when the ECHR practice should be implemented. Though, it is worth mentioning that the majority of the Ukrainian Constitution principles are based on the Convention of human rights and fundamental freedoms protection principles. The problem in this case lies in the task of the Constitutional Court of Ukraine, stipulated by legislation, must not be substituted by mere coordination of two courts' practice.

In a set of its decrees the Supreme Court of Ukraine stresses the necessity to make reference to the Convention and the European Court of Human Rights decisions. In support of that, one can mention the Supreme Court of Ukraine decree "About court decision in a civil case" 14 "About legal practice in cases on the protection of an individual's dignity and honor, and business image of individuals and legal entities". The decrees say, that on the basis of article 9 of Ukraine's Constitution regulations, and the Convention ratification and the adoption of Law № 3477-IV, the courts must make use of the Convention and the European Court decisions as the source of law ${ }^{15}$. But, mostly the Supreme Court of Ukraine does it by way of the use of the European Court of Human Rights practice, while considering specific cases of all the categories - administrative, economic, civil and criminal.

An effective means to guarantee the unity in legal practice was suggested in explanations of higher specialized courts concerning complicated and vexed questions of valid legislation, including the European Court of Human Rights practice. In this respect, emphasis should be on the Higher administrative court of Ukraine plenary session Decree "About court decision in an administrative case" of May 20 ${ }^{\text {th }}$, 2013, № 7. It acknowledged references to the European Court on Human Rights decisions while taking decision by the administrative courts. The courts should take into account, that the only reference to legislation regulations in the motivating part without proper motives of certain norms application and non-application of the other norms, being referred to by the party, substantiating its claims, can't be considered proper juridical qualification ${ }^{16}$. That is to say, the courts must give reasonable grounds to references to the European Court of Human Rights decisions in every specific case. So, the Higher administrative court of Ukraine, considering the case on the legality and substantiation of transport tax imposition, in its decree of August 30 ${ }^{\text {th }}$, 2016 on the case № K/800/8077/16 referred to the European Court of Human Rights in the cases "Serkov v. Ukraine" and "Shchokin $v$. Ukraine". These decisions determined the violation of article 1, First protocol to

12 Pro sudoustriy i status suddiv: Zakon Ukrä̈ni vid 2 chervnya 2016 r. № 1402 VIII. Vidomosti Verhovnoï Radi Ukrä̈ni. 2016. № 31. Ct. 545 zi zminami.

13 SAVENKO M. Spivvidnoshennya sudovoï praktiki Konstitutsiynogo Sudu Ukraïni iz sudovoyu praktikoyu Evropeyskogo sudu z prav lyudini. Visnik Konstitutsiynogo Sudu Ukraïni. 2006. № 1. S. 31 ..

14 Pro sudove rishennya u tsivilniy spravi: Postanova Verhovnogo Sudu Ukraïni vid 18.12.2009r. № 14. URL: http:// /ips.ligazakon.net/document/view/VS090827.

15 Pro sudovu praktiku u spravah pro zahist gidnosti ta chesti fizichnoï osobi, a takoj dilovoï reputatsiï fizichnoï ta yuridichnoï osobi: Postanova Plenumu Verhovnogo Sudu Ukraïni vid 27.02.2009r. № 1. Visnik Verhovnogo Sudu Ukraïni. 2009. № 3. S. 7.

16 Pro sudove rishennya v administrativniy spravi: Postanova Plenumu Vischogo administrativnogo sudu Ukraïni vid 20.05.2013r. № 7. URL: http://zakon2.rada.gov.ua/laws/show/v0007760-13. 
the Convention, as the government bodies gave preference to the less favorable interpretation of national legislation, what lead to imposing additional tax obligations on the part of the declarant. Taking into consideration the European Court on human rights practice, the Higher administrative court of Ukraine panel of judges concluded the imposed transport tax being illegal for $2015^{17}$. The decision was taken on the grounds of imperativeness of the rule about decision-making in favour of a tax payer.

\section{THE AMBIGUITY IN ECHR DECISIONS INTERPRETATIONS BY THE NA- TIONAL COURTS OF UKRAINE}

At the same time, the carried out legal practice analysis enables to claim about the quantity of cases with ambiguous interpretation of the same decisions of the European Court of Human Rights by national courts of Ukraine. For instance, Kyiv administrative court of appeal in its decree of February $26^{\text {th }}, 2009$ on case № 22-a-28584/08 satisfied the appeal claim of Vinnytsya RPI on the Vinnytsya district administrative court decision of June $13^{\text {th }}, 2008$ (the case of TOV "Barlinek Invest", (limited liability company) claim against Vinnytsya RPI to consider their actions illegal).

The appeal instance regards TOV "Barlinek Invest" and Vinnytsya district administrative court's references to the European Court on human rights decisions ("Intersplav $v$. Ukraine") as illegal. Kyiv administrative court of appeal states, that the Court's decision should have been taken concerning cases when confirmation of the right to receive surplus value tax is refused but not the right to change the way of such compensation provided by the tax payer in the determined in the declaration way since the moment of its presentation to tax administration $^{18}$.

Different interpretation of one and the same European Court of Human Rights legal positions appears in the decisions of one and the same national court of Ukraine. So, in the decision of January $31^{\text {st }}, 2011$ № 14/11 in the case on the claim of ZAT "Mukachivskyi lisokombinat" to Mukachiv united state tax inspection in the Transcarpathian region about tax notification illegality consideration, the Supreme Court of Ukraine stated, that "current Ukrainian legislation doesn't consider the right of the surplus value tax payer to get a tax credit according to tax legislation regulations by another subject of management, in particular, the one not being the supplier of goods on which surplus value tax was imposed. The Supreme Court of Ukraine in the above decision stressed, that such a conclusion "corresponds to the European Court on human rights practice. Another example is the case "Bulves AD v. Bulgaria" (claim № 3991/03). The European Court of Human Rights in its decision of January $22^{\text {nd }}, 2009$ stresses, that the tax payer doesn't suffer consequences of the supplier's inability to pay tax and, as a result, inability to pay surplus value tax for the second time, and to pay the fine.

In the Court's opinion, such demands have become an excessive load for the tax payer, and have broken true balance between public interest requirements and the requirements of proprietary right protection ${ }^{19}$.

But, in the decision of January $26^{\text {th }}, 2016$ in case № 21-4781a15, 2a-15327/12/2670 on the claim of TOV "Inbud XXT" (limited liability company) to Solomiansky region's administration, Kyiv, Ukraine concerning confirmation of tax notifications as those being illegal and being cancelled, the Supreme Court of Ukraine changed its legal position concerning the con-

17 Pro viznannya protipravnim ta vidminu podatkovogo povidomlennya-rishennya: Postanova Vischogo administrativnogo sudu Ukraïni vid 30.08.2016r. № 826/22028/15, K/800/8077/16.

URL: http://search.ligazakon.ua/1_doc2.nsf/link1/AS160241.html.

18 Div.: Ediniy derjavniy reestr sudovih rishen. URL: http://reyestr.court.gov.ua/..

19 Div.: Tam samo. 
firmation of tax credit on the operations with contractors, showing fictitious signs. As the Supreme Court of Ukraine stressed, "...the status of fictitious enterprise is incompatible with legal entrepreneur activity even presenting formal confirmation of its initial documents" 20 . One of the reasons of such ambiguous interpretation of the European Court of Human Rights practice is the absence of court practice generalizations on the given question.

Another illustrative example of the implementation of the mentioned above European standards by the Ukrainian judicial institutions is the decision in the case under the constitutional petition of the Commissioner of the Supreme Council (Verkhovna Rada) of Ukraine on Human Rights. According to the certain provisions of part two of Article 8 and the second sentence of part four of Article 16 of the Law of Ukraine "About the Appeal of Citizens"(Case on the Application of Persons Recognized by the Court as legally incapable) Case No. 1-124 / 2018 (4976/17) from October 11, 2018. The subject of law to constitutional application stated that the disputed provisions of the Law impose restrictions on persons recognized by the court as incapacitated. Enforcement of the right provided for by Article 40 of the Constitution of Ukraine that is to address individual or collective written applications or personally to the government, local government and public officials capable to resolve the question. They are obliged to consider the application and to give a substantiated response within the established time-limit. The Constitutional Court of Ukraine has established that in accordance with Article 55 of the Fundamental Law of Ukraine, each person has the right to protect his/her rights and freedoms from violations and unlawful violations (part sixth), by any means not prohibited by law. Moreover, to apply for the protection of his/her rights to the Commissioner of the Supreme Council (Verkhovna Rada) of Ukraine on human rights (part three).

The Court used reference to the Article 13 of the 1950 Convention for Protection of Human Rights and Fundamental Freedoms <...>. This is a part of the national legislation of Ukraine (part one of Article 9 of the Constitution of Ukraine), which guarantees each person whose rights and freedoms are recognized in the Convention as violated to have the right to an effective remedy before a national authority. Even if such an infringement had been committed by persons who had exercised their official authority.

The CCU (Constitutional Court of Ukraine) also based its decision on the fact that the European Court of Human Rights has repeatedly admitted violations of the provisions of the Convention by respondent governments due to the lack of adequate remedies for people with disabilities (SV v. Romania, §§ 65-67 Parascineti v. Romania, §§ 34-38; and SV. v. Romania (no.2), § 97). In particular, the CCU (Constitutional Court of Ukraine) noted that in the case of "Stanev v. Bulgaria" from January 17, 2012, the European Court of Human Rights expressed the view that any protective measure should, as far as possible, reflect wishes of persons with mental disorders who are capable of expressing their will. Failure to take into account their views may lead to abuses and obstacles to the implementation of the rights of vulnerable persons. Therefore, any measure adopted without previous discussion with the relevant person requires, as a rule, careful study $(\S 153)$. The Court also took into consideration the judgment in the case "Nataliya Mikhaylenko v. Ukraine" of May 30, 2013. In this Case the European Court of Human Rights admitted the applicant's right to have a fair trial guaranteed by Article $6 \S 1$ The Convention. At that time, the legislation of Ukraine did not introduce the right of persons recognized as incapacitated to have direct independent access to the court in order to renew their civil capacity $(\S 39)$. As a result, the Constitutional Court of Ukraine decided to declare that the provisions of the Law of Ukraine "On Appeal of Citizens" dated October 2, 1996 No. 393/96-VR, do not conform to the Constitution of Ukraine (they are unconstitutional). With amendments, namely: Part Two Section 8, which does not consid-

20 Div.: Tam samo. 
er "persons' applications who are recognized by the court as incapacitated " and the second sentence of part four of section 16 concerning the complaint about the interests of incapacitated persons only by their legal representatives.

\section{CONCLUSION}

The Convention of Human Rights and Fundamental Freedoms protection, as well as the European Court of Human Rights practice influence not only international human rights protection standards, but also the formation of these standards on a national level. Making use of the Strasbourg court practice, the Constitutional Court directs legislators, individuals, courts of general jurisdiction and other legal bodies toward considering European legal codicils and values while improving national legislation, solving legal cases, protecting human rights and fundamental freedoms. References to the Convention, sometimes to the European Court of Human Rights practice, prove that it considers normative regulations of the Convention as the integral part of its motivation while determining the content and limits of Constitutional guarantees of the main rights and freedoms of man and citizen. One can affirm that the Constitutional Court of Ukraine judges regard legal positions of the Court in relation to the Convention interpretation as a specific methodological concept while forming their own comprehension of the content and limits of individual rights and freedoms, recognized by the Constitution of Ukraine.

An important and complicated problem is the implementation of the European Court of Human Rights practice by Ukrainian courts in corresponding procedures and on legal grounds. The carried out analysis of court practice has allowed us to find out and systematize the problems, appearing in national courts' activity. The problems of native courts with the application of the European Court legal positions prove, that it is the Supreme Court of Ukraine that should form conceptual approaches and methods for the courts to use European standards, to work out recommendations within the framework of its jurisdiction as well as the Convention standards and the European Court of Human Rights practice.

\section{KEYWORDS}

Convention of human rights and fundamental freedoms protection, interpretation, implementation, European court of human rights, Europen standards of human rights, national legal system, mechanism of Conventional rights protection.

\section{KLƯČOVÉ SLOVÁ}

Dohoda o ochrane l'udských práv a základných slobôd, Interpretácia, Implementácia, Európsky súd pre l'udské práva, Národný právny system, Mechanizmus ochrany základných slobôd.

\section{BIBLIOGRAPHY}

1. Council of Europe; European Court of Human Rights. European Convention on Human Rights: from 4 Nov. 1950 (as amended by Protocols Nos. 11 and 14, supplemented by Protocols Nos. 1, 4, 6, 7, 12 and 13.

URL: http://www.echr.coe.int/Documents/Convention_ENG.pdf.

2. European Court of Human Rights. National Union of Belgian Police v. Belgium judgment of 27 October 1975, Separate Opinion of Judge sir Gerald Fitzmaurice. URL: http://www.echr.coe.int.

3. Ediniy derjavniy reestr sudovih rishen. URL: http://reyestr.court.gov.ua/. 
4. Kodeks administrativnogo sudochinstva Ukraïni. CHastina 2 statti 8. Vidomosti Verhovnoï Radi Ukraïni. 2005. № 35-36, № 37. St. 446. zi zminami.

5. KRETOVA I. YU. Tlumachennya prava: doktrini, rozvinuti Evropeyskim Sudom z prav lyudini: dis. kand. ... yurid. nauk: 12.00.01. Harkiv, 2015. $236 \mathrm{~s}$.

6. Kriminalniy protsesualniy kodeks Ukraïni. CHastina 2 statti 8. Vidomosti Verhovnoï Radi Ukraïni. 2013. № 9-10, № 11-12, № 13. St. 88. zi zminami.

7. MAKBRAYD Dj. Printsipi, scho viznachayut tlumachennya ta zastosuvannya Evropeyskoï konventsiï z prav lyudini. B: Jukovska O. L. (red.). Evropeyska konventsiya z prav lyudini: osnovni polojennya, praktika zastosuvannya, ukraïnskiy kontekst. Kiïv: ZAT "VIPOL", 2004. S. 761-781.

8. MAZUR M. V., TAGIEV S. R., BENITSKIY A. S., KOSTITSKIY V. V. Tlumachennya ta zastosuvannya Konventsiï pro zahist prav lyudini y osnovopolojnih svobod Evropeyskim sudom z prav lyudini ta sudami Ukraïni: navch. posib. Lugansk: RVV LDUVS, 2006. $600 \mathrm{~s}$.

9. Pro vikonannya rishen ta zastosuvannya praktiki Evropeyskogo sudu z prav lyudini: Zakon Ukraïni vid 23 lyutogo 2006 r. Vidomosti Verhovnoï Radi Ukraïni. 2006. № 30. Ct. 260 zi zminami.

10. Pro viznannya protipravnim ta vidminu podatkovogo povidomlennya-rishennya: Postanova Vischogo administrativnogo sudu Ukraïni vid 30.08.2016r. № 826/22028/15, K/800/8077/16. URL: http://search.ligazakon.ua/1_doc2.nsf/link1/AS160241.html.

11. Pro ratifikatsiyu Konventsiï pro zahist prav lyudini i osnovopolojnih svobod 1950 r., Pershogo protokolu ta protokoliv № 2, 4, 7 ta 11 do Konventsiï: Zakon Ukraïni vid 17 lipnya 1997 r. № 475/97-VR. Vidomosti Verhovnoï Radi Ukraïni. 1997. № 40. Ct. 263.

12. Pro sudoustriy i status suddiv: Zakon Ukraïni vid 2 chervnya 2016 r. № 1402 VIII. Vidomosti Verhovnoï Radi Ukraïni. 2016. № 31. Ct. 545 zi zminami.

13. Pro sudovu praktiku u spravah pro zahist gidnosti ta chesti fizichnoï osobi, a takoj dilovoï reputatsiï fizichnoï ta yuridichnoï osobi: Postanova Plenumu Verhovnogo Sudu Ukraïni vid 27.02.2009r. № 1. Visnik Verhovnogo Sudu Ukraïni. 2009. № 3. S. 7.

14. Pro sudove rishennya $\mathrm{v}$ administrativniy spravi: Postanova Plenumu Vischogo administrativnogo sudu Ukraïni vid 20.05.2013r. № 7. URL: http://zakon2.rada.gov.ua/laws/show/v0007760-13.

15. Pro sudove rishennya u tsivilniy spravi: Postanova Plenumu Verhovnogo Sudu Ukraïni vid 18.12.2009r. № 14. URL: http:// /ips.ligazakon.net/document/view/VS090827.

16. Pro zahodi schodo realizatsiï Zakonu Ukraïni «Pro vikonannya rishen ta zastosuvannya praktiki Evropeyskogo sudu z prav lyudini»: Postanova Kabinetu Ministriv Ukraïni vid 31 travnya 2006 r. № 784 . Ofitsiyniy visnik Ukraïni. 2006. № 22. Ct. 1655 zi zminami.

17. Rishennya Konstitutsiynogo Sudu Ukraïni № 1-124/2018(4976/17) vid 11 jovtnja 2018 roky. URL: https://zakon.rada.gov.ua/laws/show/en/v008p710-18

18. SAVENKO M. Spivvidnoshennya sudovoï praktiki iz sudovoyu praktikoyu Evropeyskogo sudu z prav lyudini. Visnik Konstitutsiynogo Sudu Ukraïni. 2006. № 1. S. $30-42$.

19. Uryadoviy upovnovajeniy u spravah Evropeyskogo sudu z prav lyudini. Ministerstvo yustitsiï Ukraïni. Ofitsiyniy veb-sayt. URL: http://old.minjust.gov.ua/8030. 


\section{CONTACT DETAILS OF AUTHOR}

\section{Svitlana Karvatska,}

$\mathrm{PhD}$ in Law, Associate Professor, Doctoral Candidate

Yuriy Fedkovych Chernivtsi National University, Department of Human Rights, Law Faculty, Doctoral Candidate at the Institute of International Relations Taras Shevchenko National University of Kyiv

58012 Kotsjubynskyi St. 2, Chernivtsi, Ukraine

T: +38(050)1834938

E: svitlana.karvatska288822@gmail.com 